\title{
An Analysis of Women Self-Help Group in Sivagangai District - A Case Study
}

Volume: 7

Issue: 2

Month: March

Year: 2019

ISSN: 2319-961X

Received: 6.3.2019

Accepted: 12.3.2019

Published: 15.3.2019

Citation:

Mahadevan, R. "An Analysis of Women Self-Help Group in Sivagangai District - A Case Study." Shanlax International Journal of Economics, vol. 7 , no. 2, 2019, pp. 58-61.

DOI:

https://doi.org/10.34293/

economics.v7i2.317

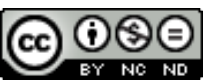

This work is licensed under a Creative Commons Attribution-NonCommercialNoDerivatives 4.0 International License

\section{R.Mahadevan}

Guest Lecturer

Alagappa University Evening College, Rameshwaram, Tamil Nadu, India

\begin{abstract}
It this study is recently fast growth of women shelf help group in Sivagangai Districts and Marketing of product and service to the people and Micro economic development. The Tamilnadu Government to announced each districts to open the department stores in women self help group and the marketing of different product in $\mathrm{SHG}$
\end{abstract}

Keywords; shelf help, product and service, different product.

\section{Introduction}

An SHG is a group of about 20 people from a homogenous class, who came tighter for addressing their common problems. They are encouraged to make voluntary thrift on a regular basis. They use this padded resource to make small interest bearing loans to their members. The process helps them imbibe the essentials of financial intermediation including prioritization of needs, setting terms and conditions accounts keeping. This gradually builds financial discipline in all of them. They also loan to handle resource, of a size that is much beyond individual, capacities of any of them. The SHG members begin to appreciate the resources that are limited and have a cost - once the groups shows this mature financial behavior, banks are encouraged to make the accumulated savings of the SHG. The bank loans are given without any collateral and at market interest rates. The groups continue to decide the terms of loans to their own members. Since the group's own accumulated savings are part and parcel the aggregate loans made by the groups to their members, peer pressure ensures timely repayments.

\section{SHGS in Tamilnadu - An Overview}

Women Below poverty Line (BPL) are the target group of Mathi. Increasingly the focus is on the poorest and the most disadvantaged, specially the scheduled casts and scheduled tribes.

There are in all 142,682 women SHGs in Tamilnadu as of September 2003 under the Mathi. These SHGs have an enrollment of 2427141 women members. They have saved a whopping Rs. $3,568 \mathrm{~m}$. The average group size is 17 members. The average savings per group is Rs. 25066 and per member is Rs. $1,470 /-$.

The growth of the SHGs in the last two years has been phenomenal and 67,435 more SHGs (90\%) have been added. 
Need of the Study

It this study is recently fast growth of women shelf help group in Sivagangai Districts and Marketing of product and service to the people and Micro economic development.

The Tamilnadu Government to announced each districts to open the department stores in women self help group and the marketing of different product in SHG. The Sivagangai District recently opened MATHA SELF HELP GROUP. So I have selected this Topic and area.

\section{Research Methodology}

Research methodology refers to the various sequential steps adopted by a researcher in studying the problem with certain objectives in mind. In this chapter, the plan, structure, strategy, tools and samples of the investigation have been discussed. In the process of conducting such an important study, the researcher has followed the following methodology to collect the necessary data and to analyze and to draw useful inference.

\section{Objective}

- To study the socio - demographic background of respondents.

- To study the sources that help in marketing.

\section{Research Design}

Research design is the conceptual framework within which the research is conducted. It is a tentative plan or blue print for the collection, measurement and analysis of data. It undergoes modifications, as they study progresses. The research design used for the study is the descriptive design.

A descriptive study is undertaken to portray accurately the characteristics of a particular group or situation. It deals with studying the attitudes and views of people regarding certain things or issues. This design is used in this study to describe the marketing ability of the self - help group women.

\section{Sample Frame}

Sample Frame is taken out of the universe. It is also known as a source list. This list should be comprehensive, correct, reliable and appropriate. The sample frame for this study will constitute the self - help group members involved in business.

\section{Area of the Study}

Sivagangai District is an administrative district of Tamil Nadu state in southern India. The city of Sivagangai is the district headquarters.

Sivaganga District has been carved out from composite Ramnad District as per G.O. MS. No. 1122 Rev. Dept. Dated. 6.7.84 and the District was functioning from 15.3.85 as per G.O Ms.No. 346 Rev. dept. Dated: 8.3.85.

The Kingdom of Ramnad originally comprised of the territories of Ramnad, Sivaganga and Pudukottai of today. Regunatha Sethupathy alias Kilavan Sethupathy, the 7th King of Ramnad reigned between 1674 and 1710. Kilavan Sethupathy, came to know of the bravery and valour of Peria Oodaya Thevar of Nalukottai, 4 Kilometres from Sholapuram near Sivaganga.

\section{Sampling Technique}

Sampling allows us to study a manageable number of people from the large group to drive inferences that are likely to be applicable to all the people of the large group. For this study, the researcher employed the simple Random Sampling Method. Simple Random Sampling refers to the sampling Technique in which each and every item or each possible sample combination in the whole population has an equal and independence change of being included in the sample.

\section{Sample Size}

Sample size refers to the number of items to be selected from the sample frame to constitute a sample. The sample size for this study is 50 self help group, each group selected one member to collect the information. Sivagangai District 1031 group formed in 2007 (registered / Unregistered), Under the control of Agriculture development office, Mahalir Thittam, Block Development Office, Trust and EDP training centres.

\section{The Selected SHG name and Place were as follows: \\ 1. Tamarai - Kalaiyarkoil (South) \\ 2. Roja - Karungulam \\ 3. Pasamalar - Velanfulam \\ 4. Durga - Puliyadithammam}


5. Cauvery- Kollangudi

6. Sembarithi - Natarajapuram

7. Indira - Kalaiyarkoil south

8. Nila-Muthur

9. Sivan - Pallithammam

10. Malar - Vaniyangudi

11. Vanavil- Sooranam

12. Kalpana-Veeramuthupatti

13. Sindhu- Vetriyur

14. Siragukal - Seena Mankalam

15. Nesam- Narputham

16. Bharathi-Natesapuram

17. Kurinji- Kurunthani

18. Sevanthi-Sevalpunchai

19. Athisayam- Kallal

20. Thangam - Seekorani

21. Indira- Vempani

22. Imayam - Sivagangai

23. Ponvizha- Valayampatti

24. Amutham - Kalaiyarkoil

25. Nila- Kayavodai

26. Sun - Sanavoorani

27. Indian- Thavusukudi

28. Amirtha-Marakathur

29. Saraswathi - Kollangudi

30. Pattu Roja - Nedunkulam

31. Poovanam - Kattathi

32. Five Star - Kalluvazhi

33. Moon - Kalaiyarkoil West

34. Indragandhi- Kollangudi

35. Kovilmani - Madathanpunchai

36. Sri Amman - Sooranam

37. Kalpana Sawla- Nemam

38. Nehru - Nedunkulam

39. White Rose - Narputham

40. Vanmathi - Manthali

41. Indhu - Aniyavayal

42. Lion - Thavusukudiu

43. Tamil - Kallal

44. Idhayam - N.Manakudi

45. Sakthi - Kattathi

46. Mercy - Kalaiyarkoil

47. Sivasakthi - Manakudi

48. Panimalar - Valaiyampatti

49. Raja Rajan - Velarenthal

50. Suter - Medupatti

\section{Tool For Data Collection}

The researcher used the interview schedule as the toll for data collection. The researcher interviewed the respondent's and filled the interview schedule accordingly. The interview schedule was prepared keeping the objectives of the study in mind.

\section{Source of Data}

The researcher used the interview schedule for the collection of primary data. For the secondary sources information, the researcher had access to various books, publications, articles, reports, newspapers and internet.

\section{Data Collection}

Collection of data from 50 respondents was carried out January 2017 and March 2018.

\section{Analysis of Data}

The collected has been systematically analyzed. The information collected has been presented in simple tables with interpretations and the researchers own accompanying inferences. These were further supported by charts and diagrams wherever necessary.

\section{Limitations}

- Filling each of other interview schedule consumer time.

- The researcher had to wait till the respondents finished off their works or meetings.

\section{Analysis and Interpretation of the Data}

This chapter contains the analysis and interpretation of the collected data. After the collection of data, the researcher coded the data and processed the data with statistical analysis. This data is presented in tabular forms with the researcher's comments following it.

Table 1: Distribution of Respondents on the basis of role

\begin{tabular}{|l|c|c|}
\hline \multicolumn{1}{|c|}{ Role } & Frequency & $\mathbf{\%}$ \\
\hline Animator & 08 & 16 \\
\hline Representative I & 07 & 14 \\
\hline Representative II & 03 & 06 \\
\hline Member & 32 & 64 \\
\hline \multicolumn{1}{|c|}{ Total } & $\mathbf{5 0}$ & $\mathbf{1 0 0}$ \\
\hline
\end{tabular}

Source: Primary data 
It is inferred from the above table that $64 \%$ of the respondents are members of the self help group and these members have involved more on business when compared to the animators and representative. $16 \%$ percent of the respondents are animators who have involved in the business as well as in motivation the members to carry out the business well, their main work is to see that the group is functioning well and the main accesses to the bank is carried out by them. Whereas the remaining percentage of the respondents are the representative I and II, who normally do the work like maintaining the accounts and other information.

\section{Chart - 1}

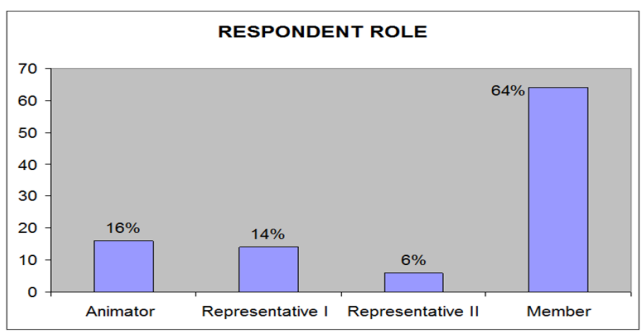

\section{Suggestion}

- The self - help group members should be given training in the production of the goods.

- They can also be made to undergo Entrepreneur Development Programme training.

- An experienced person can be appointed to inspect their group progress and give suggestion to their business.

The Non Government Organisation and government can open stalls to exhibit their products.

The members can be taught about the marketing skills and the professional way to carry out the business.

- More number of trainings can be given in a year to the members.

\section{Conclusion}

Through this research it has been concluded that, the self - help group women find difficulty, in marketing their products due to lack of training, particularly in marketing and they also find difficulty in identifying the retailers for their product. To over come all this hurdles proper training can be provided to them, twice in a year by the NGO as well as the Government.

\section{References}

http://www.entrepreneur.com/article/244210

http://www.bms.co.in/ http://yourbusiness.azcentral.com/

http://www.iba.dk/

http://ftp.iza.org/dp7507.pdf

http://www.yourarticlelibrary.com/entrepreneur

\section{Author Details}

R.Mahadevan, Guest Lecturer, Alagappa University Evening College, Rameshwaram, Tamil Nadu, India 